\title{
Supplier Entry Barriers to the Mining Global Value Chain in Zambia: A Regression Analysis
}

\author{
Peter Kanyinji ${ }^{*}$ and Prof. Gelson Tembo ${ }^{2}$ \\ ${ }^{1}$ Cavendish University Zambia \\ Lusaka, Zambia \\ ${ }^{2}$ The University of Zambia \\ Lusaka, Zambia \\ *Corresponding author's email: peterkanyinji [AT] yahoo.com
}

\begin{abstract}
There has been lots of questions on why there is continued escalating poverty levels in Zambia despite the presence of the commercial activities from the mining global value chain. These commercial activities would be helpful in linking small \& medium enterprises (SMEs) to participate in the high grade market and supply for sustainable income. Unfortunately, there are barriers of entry that limit supplier entry and participation. The Zambian mines are marred with such barriers as tax compliance, registration processes, licensing requirements, technology upgrade, standards requirements, capacity requirements, managerial competencies, competition barriers and financial constraints. The main objective of the study was to perform a regression analysis and establish the predictor barriers to supplier participation. A survey questionnaire with 350 respondents showed a Cronbach reliability test of 0.812 indicating a good internal consistence. Further Statistics from the SPSS output show the following p-values; tax (0.036), standards (0.033), individual capacity (0.01), financial capital (0.00) as predictors of supplier participation to the mines while registration (0.524), licensing (.267), technology upgrade (.079), managerial skills (.853) and competition (.383) showing that they are not predictors of suppliers' participation to the mines. This means that tax, standards, individual capacity and financial capital sit statistically significant and influence the functioning of the mining value chain
\end{abstract}

Keywords--- Participation, barriers in the mining global value chain, suppliers, small and medium enterprises

\section{INTRODUCTION}

The mining sector has been a key area in economic development in many countries through tax revenues and employment creation from its global value chain activities. The global value chain (GVC) covers the full range of activities performed by various firms to bring a product from its inception to the end user and beyond (OECD, 2013a). There are lots of benefits of mining global value chain to local communities especially when suppliers or small and medium enterprises (SMEs)are linked to their mining value chains (IFC, 2002; OECD, 2013b). Once the mines provide sustainable linkages to suppliers, there is corresponding growth in incomes for participating stakeholders in the chains (IFC, 2002; Ata, Shukla \& Singh, 2013). In Malaysia and Caribbean countries, participants in GVC have benefited greatly and have become global trotters (UNCTAD, 2010; SELA, 2012). These successful linkages are enabled by eliminating the value chain barriers (OECD, 2013a; Gereffi, 2013). In the Zambian economy, such barriers may include tax compliance, registration processes, licensing requirements, technology upgrade, standards requirements, capacity requirements, managerial competencies, competition barriers and financial constraints (Chibwe, 2008).

Zambia will continue to experience the burden of poverty unless a strategic policy intervention is made to fight it (CSO, 2012; UNDP, 2013a). The changes in the economic landscape makes businesses to be competitive and therefore SMEs must find better ways to engage with high grade markets (OECD, 2013a; Hoermann et al., 2010). Global value chains therefore have become focal points for different actors in production (Kaplinsky, (2010). However, there are barriers of entry in the global value chains (Mitchell et al., 2009: 21; OECD-APEC, 2006; Nkhonjera et al., (2016). The rationale in this study is therefore to perform regression analysis and identify the predictors influencing SMEs to participate in the mining value chain. 


\section{LITERATURE REVIEW}

In this study, global value chain (GVC) theory is being used to gain insight in the relationship between private sector production and trade on the one hand and inclusiveness of the mining global value chain on the other. The theory specifically focuses on the role of GVC in linking various players for a win-win situation as well as identifying barriers that affect the inclusion of SMEs in the mining global value chain for them to supply and earn sustainable income and poverty reduction. UNCTAD (2013) stresses that GVCs act as a route to market for export products and services which in turn directly spawns value added contributing to Gross Domestic Products, job creation, income generation, and tax income. However, there are a number of obstacles in entering GVC.

Standards are key elements of the well-functioning of the GVC, and lead firms rely on them to reduce the complexity of these transactions as they place new demands on the value chains. These standards establish products and process specifications so that wide range of global suppliers deliver according to requirements of developed-country markets, and failure to meet these standards may lead to exclusion from the GVC. Excessive high local standards for intra-GVC transaction are burdensome and may constitute unnecessary obstacles to trade (Mitchell et al., 2009: 21; Kaplinsky, 2010:2; Cattaneo et al., 2013:20-23; Tijaja, 2013:2-9). In the case of standards set by lead-firms seeking to reduce costs and increase flexibility, this may involve the definition of minimum levels of permitted defects.

Tax in most countries worldwide exist as a barrier to trade. The tax structure does not adequately address the needs of SMEs, and hence create a greater burden to the tax-payers and ultimately affecting the final consumer due to the shifting ability of tax (Mnewa and Maliti, 2008; UNIDO, 2009). In addition, most of the tax policies do not favor SMEs' growth and productivity. In most countries, there are inflexible laws which affect suppliers to participate in the global value chains. Furthermore, non-tariff measures (NTMs) have become obstacles affecting a country's participation in the GVC irrespective of the governance structure of the chains

Registration and licensing policies under which the private sector is operating and regulated by government act as barriers of entry to supply to the mines. These policies aim at ensuring free and fair competition as well as decent and productive work of all stakeholders (Kanbur \& Venables, 2005). However, some regulations under which private sector is governed are obsolete and do not favor innovation and entrepreneurship development. It is true that some administrative procedures may have been relevant at some point in time, but have become redundant and barriers as they do not meet the intended objectives (Kanbur \& Venables, 2005; Kaplinsky 2010; Mitchell et al., 2009; Tijaja, 2013).

Upgrading technology has continued to act as barriers of entry to the mines as they are beyond the scope of SMEs. There is a growing concern in both developed and developing countries over the economic gains of participating in global value chains that they do not necessarily translate into good jobs or stable employment. There has been greater need to upgrade to participate in value chain but Gereffi (2013) contend that economic upgrading may be linked to a significant deterioration of labor conditions and other forms of social downgrading. A major question is to what conditions can participating in GVCs contribute to both economic and social upgrading in developing as well as developed countries and firms? (Lee et al., 2011:35; Gereffi, 2013:9-10). In the GVC framework, there are four types of upgrading (product, process, functional and chain upgrading) which firms may adopt to help 'climb the value chain' from basic assembly activities using low-cost and unskilled labor to more advanced forms of 'full package' supply and integrated manufacturing (Humphrey \& Schmitz, 2000:2-8). These upgrading trajectories are not cheap and attainable by suppliers (Humphrey, 2004), as they require performance improvement, quality improvement, technology improvement (UNIDO, 2004), and learning opportunities (UNCTAD, 2010; OECD, 2013) which are beyond their scope.

Poor innovation and creativity is a limitation for SMEs to participate in GVC. Capacities and productivity have continued to be tipping points for foreign investor's decisions and lead firms. Since a country does not require to develop an integrated industry to participate in international trade, GVC therefore make it easier to reduce constraints. UNCTAD (2010) cited by Cattaneo et al., (2013) stress that given the predominance of flows in the new paradigm, adaptability to lead firms' request, responsiveness, and capacity to innovate are key factors. Determinants for a country's participating in the GVC may include; capacity for scale of production which may be beyond local SMEs, availability of services necessary to support production and market integration, education and skills of the workforce matching the needs of global producers and buyers, and capacity for innovation in its multiple dimension, environmental sustainability (Cattaneo et al., 2013:27), cheap and reliable energy, finance and trade support, telecommunication, and transports.

There is poor management skills and financial resources (OECD-APEC, 2006) among the suppliers. In addition, suppliers are not able to upgrade and protect in-house technology (OECD, 2007b) which is a barrier of entry into GVC (Quinn et al., 2012; SELA, 2012). According to EFIC (2008), and Bhatti \& Kumar (2012) lack of awareness of economic and noneconomic benefits of export markets is a limiting factor. SMEs also lack the scale to invest in research and development (R\&D), 
train personnel and meet strict standards and quality requirements and in addition, OECD (2007b:1) as well as Van Wijk \& Kwakkenbos (2011:2) stress that SMEs lack access to knowledge, technology, credit and markets. OECD (2013b) and Van Dijk \& Trienekens (eds.) (2012) lists barriers of entry as inadequate quantity of or untrained personnel for internationalization, shortage of working capital to finance export, limited information to locate and analyses markets. In addition, access to trade finance, compliance with standards, lack of comparative advantage, and high market entry costs are common barriers of entry into GVC (OECD-APEC, 2006; OECD/WTO, 2013a, OECD/WTO 2013b)

As regards competitiveness, Caspari (2003) show that firm size is a barrier in participating in global value chain. Most global firms concentrate on highest value added parts of the global value chain from selected suppliers who have the capacity to fulfil orders on time, and supply the required quality. Gereffi's (2000) analysis of the apparel industry in North America show that the investment requirements needed for high value activities are out of reach of the SMEs. However, it is important to note that in the value chain, there is an opportunity for learning, partnerships and upgrading (UNIDO, 2004).

\section{METHODOLOGY}

\subsection{Introduction}

The research methodology involved testing the relationship between factors existing as barriers and participation in the mining global value chain. The barriers of entry have been categorized as tax, registration, licensing, technology, standards, capacity, managerial, competition and financial constraints. A regression analysis was done to determine the correlation coefficient between barriers of entry and the level of participation in the global value chain. The study used a survey method to collect data from a total of 350 suppliers. The questionnaire was based on nine (9) variables - tax, registration, licensing, technology, standards, capacity, managerial, competition and financial constraints and how they impact on participation. "Participation" in the study refers to suppliers' chance to supply to the mines. Once they supply and earn income, then they have participated in the mining global value chain. The measurement scales range from strongly agree (5), agree (4), undecided (3), disagree (2) and strongly disagree (1).

\subsection{Operationalization}

Table 1.0: Operationalization of variables

\begin{tabular}{|l|l|}
\hline Tax barriers & Tax is very high, Cumbersome Tax registration \& tax is unstable \\
\hline Registration barriers & Cumbersome registration, Cost of registration is high, Limited time for registration \\
\hline Licensing barriers & (Bureaucratic licensing, too many licenses \& Cost of licensing); \\
\hline Technology barriers & Technology barriers (expensive technology, installation cost \& technology changes \\
\hline Standards & ISO certificate, improved technology, ethical principles \\
\hline capacity barriers & volume of products, quality of products, reliability \\
\hline managerial barriers & competency, skilled, experienced \\
\hline competition & quality, time, cost effectiveness \\
\hline financial barrier & ability to buy raw materials, working capital, good credit rating \\
\hline Participation & $\begin{array}{l}\text { Number of units supplied to the mines, number of orders from the mines requesting suppliers to } \\
\text { supply them with products and services, }\end{array}$ \\
\hline
\end{tabular}

The operationalization shown in table 1.0 show indicators of the independent variables and the dependent variable. The independent variable include; tax, registration, licensing, technology, standards, capacity, managerial, competition and financial barriers. The dependent variable is "participation".

\subsection{Data analysis}

Reliability whose Cronbach's alpha ranges from 0 to 1 tests for internal consistency. Values closer to 1.0 indicate a greater internal consistency of the variables in the scale. In other words, higher Cronbach's alpha values show greater scale reliability. A value of 1.0 indicates that all of the variability in test scores are due to true score differences. The ANOVA test 
was done to show overall if the independent variable is a predictor of the dependent variable and the extent to which is statistically significant. In the study, the ANOVA test was a way to find out if the survey results were significant and helpful to figure out if we have to reject the null hypothesis or accept the alternative hypothesis. The regression coefficients individually show if the independent variables are statistically significant.

\section{RESULTS}

\subsection{Reliability statistics}

Table 2.0: Reliability Statistics

\begin{tabular}{|c|c|}
\hline Cronbach's Alpha & N of Items \\
\hline .812 & 10 \\
\hline
\end{tabular}

The reliability test statistics in Table 2.0 show Cronbach value of 0.812 using SPSS. According to Saunders et al., (2009), Cronbach's alpha is used as a measure of internal consistency of a psychometric instrument.. Other researchers such as Hair et al., (2010) indicated that values of 0.70 are generally agreed upon as an acceptable value. It is important to note that although the Cronbach alpha may be high, it does not imply that the measure is unidimensional but it is just a coefficient of reliability or consistency

\subsection{Multiple correlation measure}

Table 3.0: Model Summary

\begin{tabular}{|c|c|c|c|c|}
\hline Model & $\mathrm{R}$ & R Square & Adjusted R Square & $\begin{array}{l}\text { Std. Error of the } \\
\text { Estimate }\end{array}$ \\
\hline 1 & $.608^{\mathrm{a}}$ & .370 & .353 & .809 \\
\hline
\end{tabular}

a. Predictors: (Constant), Competition barriers arising from large firms put SMEs at risk of not suppling to the mines, Capacity to meet the mines requirement have been one of the barriers facing SMEs to supply to the mines, Registration process have been very cumbersome and one major barrier that SMEs face to supply to the mines, Tax compliance has been a major barriers that SMEs face to supply to the mines, Managerial skills to has been a major setback for SMEs to participate in supplying the mining sector, Standards requirement are expensive and have been one major barriers for SMEs to supply to the mines , Licenses requirement in various government institutions have been inhibiting the SMEs to supply to the mines, Technology requirement has been very restrictive as it is expensive and beyond reach for SMEs to adapt and attain it, Financial capital has been limiting and affected the SMEs to supply to the mines

An extract from output of SPSS in Table 3.0 show Multiple R-value of 0.609 and R-Square of 0.370. This means that in terms multiple $\mathrm{R}$, the correlation between barriers of entry and participation is $60.8 \%$ while R-Squared of $37.0 \%$ indicating that in the model, we can only account for $37 \%$ of the variance in SME participation in the mining global value chain. 


\subsection{Analysis of variance}

Table 4.0 ANOVA ${ }^{\mathrm{a}}$

\begin{tabular}{|l|l|c|c|c|c|c|}
\hline \multicolumn{2}{|l|}{ Model } & Sum of Squares & Df & Mean Square & F & Sig. \\
\hline 1 & Regression & 130.628 & 9 & 14.514 & 22.199 & $.000^{\mathrm{b}}$ \\
\hline & Residual & 222.301 & 340 & .654 & & \\
\hline & Total & 352.929 & 349 & & & \\
\hline
\end{tabular}

a. Dependent Variable: I have been participating in the mining value chain by supplying to the mine

b. Predictors: (Constant), Competition, Capacity, Registration, Tax, Managerial skills, Standard, Licenses, Technology upgrade, Financial capital.

Table 4.0 indicates that the regression model predicts the dependent variable significantly well. The regression analysis show that barriers of entry in GVC is statistically significant predictor of SME participation in the GVC. The p-value shows 0.000 which is less than 0.05 . In summary, the regression model statistically significantly predicts the outcome variable which is a good fit for the data. 


\subsection{Regression coefficient measure}

Table 5.0: Statistics on regression coefficients

\begin{tabular}{|c|c|c|c|c|c|c|c|c|}
\hline \multicolumn{9}{|c|}{ Regression Coefficients } \\
\hline & \multirow[b]{2}{*}{ Model } & \multicolumn{2}{|c|}{$\begin{array}{l}\text { Unstandardized } \\
\text { Coefficients }\end{array}$} & \multirow{2}{*}{$\begin{array}{c}\text { Standardized } \\
\text { Coefficients } \\
\text { Beta }\end{array}$} & \multirow[b]{2}{*}{$\mathrm{T}$} & \multirow[b]{2}{*}{ Sig. } & \multicolumn{2}{|c|}{$\begin{array}{l}\text { 95.0\% Confidence Interval for } \\
\text { B }\end{array}$} \\
\hline & & B & $\begin{array}{l}\text { Std. } \\
\text { Error }\end{array}$ & & & & Lower Bound & Upper Bound \\
\hline 1 & (Constant) & .549 & .187 & & 2.940 & .004 & .182 & .916 \\
\hline & $\begin{array}{l}\text { Tax compliance has been } \\
\text { a major barriers that } \\
\text { SMEs face to supply to } \\
\text { the mines }\end{array}$ & .078 & .037 & .103 & 2.108 & .036 & .005 & .150 \\
\hline & $\begin{array}{l}\text { Registration process have } \\
\text { been very cumbersome } \\
\text { and one major barrier that } \\
\text { SMEs face to supply to } \\
\text { the mines }\end{array}$ & .026 & .040 & .030 & .638 & .524 & -.054 & .105 \\
\hline & $\begin{array}{l}\text { Licenses requirement in } \\
\text { various government } \\
\text { institutions have been } \\
\text { inhibiting the SMEs to } \\
\text { supply to the mines }\end{array}$ & -.048 & .044 & -.061 & -1.111 & .267 & -.134 & .037 \\
\hline & $\begin{array}{l}\text { Technology requirement } \\
\text { has been very restrictive } \\
\text { as it is expensive and } \\
\text { beyond reach for SMEs } \\
\text { to adapt and attain it }\end{array}$ & .088 & .050 & .125 & 1.763 & .079 & -.010 & .187 \\
\hline & $\begin{array}{l}\text { Standards requirement } \\
\text { are expensive and have } \\
\text { been one major barriers } \\
\text { for SMEs to supply to the } \\
\text { mines }\end{array}$ & -.098 & .046 & -.126 & -2.135 & .033 & -.189 & -.008 \\
\hline & $\begin{array}{l}\text { Capacity to meet the } \\
\text { mines requirement have } \\
\text { been one of the barriers } \\
\text { facing SMEs to supply to } \\
\text { the mines }\end{array}$ & .145 & .042 & .175 & 3.486 & .001 & .063 & .227 \\
\hline & $\begin{array}{l}\text { Managerial skills to has } \\
\text { been a major setback for } \\
\text { SMEs to participate in } \\
\text { supplying the mining } \\
\text { sector }\end{array}$ & .008 & .045 & .010 & .186 & .853 & -.080 & .097 \\
\hline & $\begin{array}{l}\text { Financial capital has } \\
\text { been limiting and } \\
\text { affected the SMEs to } \\
\text { supply to the mines }\end{array}$ & .329 & .054 & .451 & 6.038 & .000 & .222 & .436 \\
\hline & $\begin{array}{l}\text { Competition barriers } \\
\text { arising from large firms } \\
\text { put SMEs at risk of not } \\
\text { suppling to the mines }\end{array}$ & .049 & .056 & .069 & .873 & .383 & -.062 & .160 \\
\hline
\end{tabular}


Statistics from the SPSS output in Table 5.0 show among others p-values of Tax (0.036), standards (0.033), individual capacity (0.01), and financial capital (0.00). This means that they are predictors of supplier participation to the mines while registration (0.524), licensing (.267), technology upgrade (.079), managerial skills (.853) and competition (.383) are not predictors of suppliers' participation to the mines. This means that tax, standards, individual capacity and financial capital sit statistically significant and influence suppliers in the mining global value chain.

Qualitative data show that suppliers were not mandated to upgrade their technology in order to supply to the mine. One of the supplier said"

"we do not need technology to manufacture goods to supply to the mines but we buy locally or import for resale to the mines. Sometimes, we act as middlemen to sale quality goods".

Further, suppliers to the mines indicated that managerial skills and competition not are factors to influence the supply chains. It was mentioned that by one supplier that

"we don't need management skills but practical experience to supply to the mines. In addition, there is no competition in supplying to the mines as we all have equal opportunities as members of the mining suppliers and contractors association of Zambia"

On the other hand, tax was regarded as a serious barrier for SMEs to supply to the mines. One supplier said,

"Tax compliance is very expensive as we have to renew the tax compliance certificate annually even if we do not supply.

As regards standard requirement, one supplier stressed that

"we ensure that we import quality goods and re-sale to the mines to meet their standard requirement. In addition, "our individual capacity and financial capital is limiting us to supply to the mines"

\subsubsection{B - values (Unstandardized coefficients)}

These are the values for the regression equation for predicting the dependent variable from the independent variable. The regression equation is presented in many different ways but in this study, an example is given:

\section{Ypredicted $=b 0+b 1 * x 1+b 2 * x 2+b 3 * x 3 \ldots . . . b 9 * x 9$.}

The columns in table 6.0 showing estimates that provides the values for b0, b1, b2, b3 up to b9 for this equation.

i) Tax barrier: The coefficient for tax barrier is .549. So for every unit increase in tax barrier, a 0.549 unit increase in supplier participation is predicted, holding all other variables constant.

ii) Registration barriers: The coefficient for registration is .026. So for every unit increase in registration, we expect an approximately .026 point increase in the supplier participation, holding all other variables constant.

iii) Licensing barriers: The coefficient for licensing barrier is -.048. we expect a -.048 unit decrease in the supplier participation, holding all other variables constant

iv) Technology barriers: The coefficient for technology barriers is .088. So for every unit increase in technology, we expect an approximately .088 point increase in the supplier participation, holding all other variables constant.

v) Standards barriers: The coefficient for standards is -.098. we expect a -.098 unit decrease in the supplier participation, holding all other variables constant

vi) Supplier capacity: The coefficient for supplier capacity barrier is .145 . So for every unit increase in supplier capacity, we expect an approximately .145 point increase in the supplier participation, holding all other variables constant

vii) Managerial barriers: The coefficient for managerial barrier is .008. So for every unit increase in managerial barriers, we expect an approximately .008 point increase in the supplier participation, holding all other variables constant

viii) Financial capital barrier: The coefficient for financial capacity barrier is .329. So for every unit increase in financial capacity barrier, we expect an approximately .329 point increase in the supplier participation, holding all other variables constant

ix) Competition barrier: The coefficient for competition barrier is .049. So for every unit increase in competition barrier, we expect an approximately .049 point increase in the supplier participation, holding all other variables constant 


\subsubsection{Beta Values (standardized coefficients)}

These are the standardized coefficients of all of the variables in the regression, including the dependent and all of the independent variables. By standardizing the variables before running the regression, it put all of the variables on the same scale, which were then compared on the magnitude of the coefficients to see which one has more of an effect. It is important to take note that the larger betas are associated with the larger t-values and lower p-values.

\subsubsection{T and Sig test values}

These are the t-statistics and their associated 2-tailed p-values used in testing whether a given coefficient is significantly different from zero. Using an alpha of 0.05 :

i) The coefficient for tax barrier (.103) is significantly different from 0 because its p-value is .036, which is less than 0.05 .

ii) The coefficient for registration barrier (.030) is not significantly different from 0 because its p-value is .524, which is larger than 0.05 .

iii) The coefficient for licensing barrier (-.061) is not statistically significantly different from 0 because its p-value is .267 which is definitely larger than 0.05 .

iv) The coefficient for technology barrier (.125) is not statistically significantly different from 0 because its p-value is .079 which is definitely larger than 0.05 .

v) The coefficient for standard barriers (-.126) is significantly different from 0 because its p-value is .033, which is less than 0.05 .

vi) The coefficient for capacity barriers (.175) is significantly different from 0 because its p-vale is .001 , which is less than 0.05

vii) The coefficient of managerial skills barriers (.010) is not significantly different from 0 because its p-value is .853 , which is larger than 0.05

viii) The coefficient of Financial capital barrier (.451) is significantly different from 0 because its p-vale is .000, which is less than 0.05

ix) The coefficient of Competition barrier (.069) is not significantly different from 0 because its p-value is .383, which is larger than 0.05

$\mathrm{x}$ ) The intercept is significantly different from 0 at the 0.05 alpha level.

It is important to note that if the t-value is smaller than the hypothesized value, then the t-statistic will be negative. If it is larger, the t-statistic will be positive. But it really makes no difference which sign it has because both signs are interpreted the same way as evidence against the null hypothesis. In this case, our statistic is the difference between sample means and our hypothesized value is 0 . The hypothesized value is the null hypothesis that the difference between population means is 0 . When doing a t-test, the alternative hypothesis can either be one-sided or two-sided. Further, it is important to note that if we are doing a two-sided test, then finding that the sample mean is larger or smaller than the hypothesized mean should be taken as evidence against the null hypothesis and in favor of the alternative. Then the p-value is computed to quantify the strength of the evidence. But what matters in the context of our question is that the sample mean can be smaller or larger than the hypothesized mean and still be interpreted as evidence against the null hypothesis.

\section{RECOMMENDATION}

i) Zambia National Content Development and Monitoring Board must be formed by the government through an Act of Parliament so that various "local Content Committees for specific economic sectors" will ensure that a certain share of factors of production required at various stages of the value chain is sourced from the domestic economy.

ii) Creation of the Supplier Development Working Group comprising executives from the mines, Mining suppliers and contractors association of Zambia, NGOs, and the ministry of mines whose task will be to identify and implement global value chain governance strategies, economic, social and technological upgrading of SMEs, supplier and buyer 
partnerships, on-site technical support and business development and any economic program of the non-functional supplier development programme so that SMEs build capacity for competitiveness

iii) The Citizenship Economic Empowerment Commission must be transformed from merely offering micro-credits to selected sectors of the economy into a Business Incubator for SME development so that its local incubation facilities and innovation system are created for nurturing SMEs providing integrated technical and business development support to SMEs, mentoring and coaching SMEs, technology upgrading for competitiveness to SMEs participation in the mining global value chain

\section{REFERENCES}

[1] Caspari, C. (2003). Participation in Global Value Chains as a Vehicle for SMEs upgrading: A literature review: Series on upgrading in small enterprise clusters and global value chains. Seed Working Paper No.44. InFocus Programme on Boosting Employment through Small Enterprise Development Job Creation and Enterprise Development. Geneva: International labour Organisation.

[2] Cattaneo, O., Gereffi, G., Miroudot, S., \& Taglioni, D. (2013). Joining, Upgrading and being competitive in Global Value Chains: A strategic framework. The World Bank: Poverty Reduction and Economic Management Network: International Trade Department. Policy Research Working Paper 6406

[3] Chibwe, C. (2008). Unlocking the Potential of Zambian Micro, Small and Medium Enterprises "Learning from the international best practices - the Southeast Asian Experience: IDE Discussion Paper. No. 134. 2008.2. Institute of developing economies.

[4] Dijk,M.P. Van., \& Trienekens,J.H. (eds). (2012). Global Value chains: Linking local producers from developing countries to international markets. Amsterdam:Amsterdam University Press \& EADI

[5] EFIC. (2013). Global Readiness Index - National results. New South Wales: Export Finance and Insurance Corporation.

[6] Field, A. (2005). Discovering Statistics using SPSS for Windows ( $2^{\text {nd }}$ edition). London: Sage publications.

[7] Gereffi, G. (2000). The Transformation of the North American Apparel Industry: Is NAFTA a curse or a Blessing? Inter-American Development Bank: Integration \& Trade, Vol.4 (11), 47-95.

[8] Gereffi, G. (2013). Global Value Chains in a Post-Washington Consensus World: Review of International Political Economy: North Carolina, USA: Duke University.

[9] Gereffi, G., \& Fernandez-Stark, K. (2011). Global value chain analysis: A Primer: Centre on globalization, governance and competitiveness. North Carolina, USA: Duke University.

[10] Gibbon, P. (2003). Commodities, Donors, and Value-Chain Analysis and Upgrading. DIIS. Prepared for UNCTAD.

[11] Gibbon, P., \& Ponte, S. (2005). Trading Down: Africa, Value Chains, and the Global Economy. Philadelphia, PA: Temple University Press.

[12] Hair, J. F., Black, W. C., Babin, B. J., \& Anderson, R. E. (2010). Multivariate data analysis: Pearson College Division

[13] Hoermann, B., Choudhary, D., Choudhury, D., \& Kollmair, M. (2010). Integrated Value Development as a Tool for Poverty Alleviation in Rural Mountain Area: An analytical and Strategic framework. Kathmandu, Nepal: International Centre for integrated Mountain Development.

[14] Humphrey, J. (2003). Opportunities for SMEs in Developing Countries to Upgrade in a Global Economy, ILO SEED Working Paper No. 43, Geneva.

[15] Humphrey, J. (2004). Upgrading in the global value chains. Policy International Department: World Commission on the Social Dimension of globalization. International Labour Office, Geneva. Paper No.28

[16] Humphrey, J. (2005). Shaping Value Chains for Development: Global Value Chains in Agribusinesses. Brighton: Institute of Development studies

[17] Humphrey, J., \& Schmitz, H. (2000). Governance and Upgrading: Linking Industrial Cluster and Global Value Chain Research, IDS Working Paper 120. Brighton: Institute of Development Studies

[18] IFC. (2002). Global mining: Large Mines and Local Communities: forging partnerships, building Sustainability. World bank and International finance corporation. Retrieved from http://siteresources.worldbank.org/INTOGMC/Resources/largemineslocalcommunities.pdf 
[19] IFC (2015). Large Mines and Local Communities: Forging Partnerships, Building Sustainability. Washington DC. World Bank and International Financing Corporation

[20] Kaiser, H. F. (1974). An index of factorial simplicity. Psychometrika, 39, 31-36

[21] Kaplinsky, R. (2010). The role of Standards in Global Value chains: The World Bank. Poverty Reduction and Economic Management Network: International Trade Department. Policy Research Working Paper 5396.

[22] Kaplinsky, R., \& Readman, J. (2001). Integrating SMEs in global value chains: Towards Partnership for Development. Brighton: Centre for Research in Innovation Management, University of Brighton in cooperation with staff of the Private Sector Development Branch of UNIDO.

[23] Lee, J., Gereffi, G., \& Barrientos, S. (2011) 'Global Value Chains, Upgrading and Poverty Reduction', Capturing the Gains Briefing Note No. 3. Retrieved from http://www.capturingthegains.org/pdf/ctg briefing note 3.pdf

[24] Mitchell, J., \& Ashley. C. (2009). Value chain analysis and poverty reduction at scale: Evidence from tourism is shifting mindsets. Briefing Paper 49. London: Overseas Development Institute. Retrieved from http://www.odi.org/sites/odi.org.uk/files/odi-assets/publications-opinion-files/3528.pdf

[25] Mnewa, R. \& Maliti, E. (2008). The role of small business in poverty alleviation: The case of Dar es Salaam, Tanzarnia.. S.I., Research Report 0802, Dar es Salaam, REPOA. Retrieved from http://www.repoa.or.tz/documents/08.2_Mnenwa and_Maliti_pdf

[26] Nkhonjera, P.,N,M; Paremoer,T., \& Zengeni, T. (2016). Competition, barriers to entry and inclusive growth: Agro-processing. Working Paper 3/2016. Johansburg: Centre for Competition, Regulation and Economic Development, University of Johannesburg

[27] OECD-APEC. (2006). The Athens Actions Plan for removing barriers to SMEs access to International Markets: Adopted at the OECD APEC Global conference in Athens. Retrieved from http://www.oecd.org/cfe/smes/37818332.pdf

[28] OECD. (2007a). Enhancing the role of SMEs in Global value chains: The Tokyo Action statement for strengthening the role of SME in global Value chains: Global conference, Tokyo. Retrieved from http://www.oecd.org/japan/38774814.pdf.

[29] OECD. (2007b). enhancing the role of SMEs in Global Value Chains: OECD Global Conference in Tokyo 31May-1June, 2007: OECD Background Report. Retrieved from http://vi.unctad.org/furstchains/docs/background.pdf

[30] OECD. (2013a). Interconnected Economies: Benefiting from Global Value Chains. Synthesis Report. Retrieved from http://www.oecd.org/sti/ind/interconnected-economies-GVCs-synthesis.pdf.

[31] OECD. (2013b). Centre for Entrepreneurship, SMEs, and local Development fostering SMEs participation in Global Markets: Final report CFE/SME(2012)6. Retrieved from http://search.oecd.org/officialdocuments/publicdisplaydocumentpdf/?cote=FE/SME\%282012\%296/FINAL\&d ocLanguage $=$ En.

[32] OECD/WTO. (2013a). Aid for Trade at a Glance 2013: Connecting to Value Chains. Retrieved from http://dx.doi.org/10.1787/aid_glance-2013-en

[33] OECD/WTO. (2013b). Aid for Trade and Value Chains in Agrifood. Retrieved from http://www.wto.org/english/tratop_e/devel_e/a4t_e/global_review13prog_e/agrifood 47.pdf

[34] Saunders, M., Lewis, P., \& Thornhill, A. (2009). Research Methods for Business Students. (5edn). Harlow: Pearson Education Limited

[35] SELA. (2012). Value chain, SMEs and public policies. International experiences, and lessons for Latin America, and the Caribbean. Intra-Region Relations: Forum on the design of public policies: SMEs insertion into global and regional value chains: SP/FDPP: IPYMESCVGR-DT $N^{\circ}$ 2-12. Caracas: Sela. Retrieved from http://www.sela.org/attach/258/default/DT_212 Value chains_SMEs_Public_policies_International_Experiences_Lesson_LAC.pdf

[36] Tijaja, J. (2013). Real sector: Standards in Global Value Chains: Rationale, Role and Implications. Hong Kong: Fung Global Institute

[37] UNCTAD. (2010). Integrating Developing Countries' SMEs into Global Value Chains: UNCTAD/DIAE/ED/2009/5. New York \& Geneva: United Nations

[38] UNCTAD. (2013). World Investment Report 2013: Global Value Chains: Investment and Trade. New York and Geneva: United Nations (Helmsing \& Vellema, 2011.

[39] UNDP. (2013a). Millennium Development Goals Progress Report 2013. Lusaka, Zambia: ～New $\quad$ Printing Press. 
[40] UNIDO. (2004). Inserting local Industries into Global Value chain and Global Production Networks: Opportunities and Challenges for upgrading with a focus on Asia, Chinas rising competitiveness Development Organization

[41] Zhang, G. (2009). Beyond Typologies of Global Value Chan Governance: The Accumulation of Technological Capabilities. International Journal of Business. 